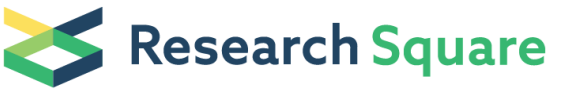

Preprints are preliminary reports that have not undergone peer review. They should not be considered conclusive, used to inform clinical practice, or referenced by the media as validated information.

\section{Assessing Preventive Health Behaviors from COVID- 19 Based on the Health Belief Model (HBM) among People in Golestan Province: A Cross-Sectional Study in Northern Iran}

\section{Hossein Shahnazi}

Associate Professor, Ph.D of Health Education and Promotion, Department of Health Education and Promotion School of Health, Isfahan University of Medical Sciences, Isfahan, Iran

Maryam Ahmadi-Livani

Bsc Student of Public Health, Faculty of Health, Golestan University of Medical Sciences, Gorgan, Iran

\section{Bagher Pahlavanzadeh}

PhD of Biostatistics, Department of Biostatistics, School of Allied Medical Sciences, Shahid Beheshti University of Medical Sciences, Tehran, Iran.

\section{Abdolhalim Rajabi}

Ph.D. of Epidemiology, Faculty of Health, Environmental Health Research Center, Golestan University of Medical Sciences, Gorgan, Iran.

\section{Mohammad Shoaib Hamrah}

Center for Rural Health, School of Health Sciences, University of Tasmania

\section{Abdurrahman Charkazi ( $\sim$ rcharkazi@yahoo.com )}

Assistant Professor, Ph.D of Health Education and Promotion, Environmental Health Research Center, Faculty of Health, Golestan University of Medical Sciences, Gorgan, Iran

\section{Research Article}

Keywords: COVID-19, Health belief model (HBM), Fatalism, Preventive behaviors, Iran

Posted Date: April 27th, 2020

DOI: https://doi.org/10.21203/rs.3.rs-24871/v1

License: (a) (i) This work is licensed under a Creative Commons Attribution 4.0 International License. Read Full License 


\section{Abstract}

Background: COVID-19 is a new viral disease that has caused a pandemic in the world. Due to the lack of vaccines and definitive treatment, preventive behaviors are the only way to overcome the disease. Therefore, the present study aimed to determine the preventive behaviors from the disease based on constructs of the health belief model.

Methods: In the present cross-sectional study during March 11 to 16, 2019, 750 individuals in Golestan province of Iran were included in the study using the convenience sampling and they completed the questionnaires through cyberspace. Factor scores were calculated using the confirmatory factor analysis. The effects of different factors were separately investigated using the univariate analyses, including students sample t-test, ANOVA, and simple linear regression. Finally, the effective factors were examined by the multiple regression analysis at a significant level of 0.05 and through Mplus 7 and SPSS 16.

Results: The participants' mean age was $33.9 \pm 9.45$ years; and $57.1 \%$ of them had associate and bachelor's degrees. Multiple regression indicated that the mean score of preventive behavior from COVID-19 was higher in women than men, and greater in urban dwellers than rural dwellers. Furthermore, one unit increase in the standard deviation of factor scores of self-efficacy and perceived benefits increased the scores of preventive behavior from COVID-19 by 0.22 and 0.17 units respectively. On the contrary, one unit increase in the standard deviation of factor score of perceived barriers and fatalistic beliefs decreased the scores of the preventive behavior from COVID-19 by 0.36 and 0.19 units respectively.

Conclusion: Results of the present study indicated that female gender, perceived barriers, perceived selfefficacy, fatalistic beliefs, perceived interests, and living in city had the greatest preventive behaviors from COVID-19 respectively. Preventive interventions were necessary among men and villagers.

\section{Background}

Since December 8, 2019, clusters of pneumonia cases have been reported with unknown reasons in Wuhan, Hubei Province, China $(1,2)$. The history of going to the market for marine products and wildlife in Wuhan was found in the early clusters of patients with the infection, suggesting the possibility of zoonotic transmission(3). The cause of this unknown pneumonia was the severe acute respiratory syndrome coronavirus 2 (SARS-CoV-2) and it has now spread to a great number of countries. On January 30, 2020, the World Health Organization's Emergency Committee considered it as a global health emergency due to its significant growth in China and other countries, and declared it to be a pandemic in March 2020(4).

SARS-COV-2 has a genetic similarity of 96 percent to corona virus originated from bats (5). The virus seemed to be transmitted from animals to humans in Huanan seafood market in Wuhan of China (6). Early symptoms of SARS-COV-2 are related to COVID-19 that occurs with pneumonia symptoms. Recent reports indicate gastrointestinal symptoms and asymptomatic infections, especially in children (3). Its incubation period is with mean of 5 days and median of 3 days and a range of $0-24$ days $(5,7)$. Clinical manifestations of the 
disease usually occur within less than a week. The symptoms include fever, cough, nasal inflammation, fatigue, and other signs of upper respiratory tract infection(7).

A feature of the SARS-COV-2 is its high virulence. Results of the recent study on 425 patients indicated that the number of patients doubled per week in the current pandemic; and each patient infected 2.2 individuals on average(3). Analysis of recent results from the early stages of the outbreak also indicated that the rate ranged from 2.2 to 3.58 individuals (8).

In Iran, the first case was reported in Qom on February 19, 2020, and then it spread to other regions of Iran. Until April 10, 2020, 66,220 individuals had the disease and 4110 died in Iran (9). The disease has been reported in 197 countries so far; and 1521252 cases of coronavirus were reported worldwide until April 10, 2020 according to Johns Hopkins University. 92798 of the patients died from the disease. Iran ranks sixth after China, Italy, the United States, Spain and Germany (10).

No vaccine or definitive treatment has been found for the disease so far, and the treatments are symptomatic and supportive. Therefore, prevention and control of this pandemic by observing the rules of prevention and personal hygiene, such as washing hands regularly with soap and water, covering mouth and nose when coughing and sneezing, and not touching the nose, mouth and eyes are the only ways to cope with the disease. Each person is the most important factor in promoting health; and the right or wrong behaviors are influenced by the individuals' beliefs, values, tendencies, and habits (3). Sociologists, psychologists, and anthropologists have proposed a range of different theories and models to explain the factors influencing the health behavior, one of which is the health belief model (HBM). This model is introduced by Rosenstock et al. and is a general conceptual framework and theoretical guideline for health behaviors in the public health research, and it consists of constructs, namely the perceived susceptibility, perceived severity, perceived benefits, perceived barriers, cues to action, and preventive health behaviors $(11,12)$. The general acceptance and popularity of the health belief model is due to its high predictive power(12). The model is designed to explain the reasons why people do not participate in the prevention program and is based on the hypothesis that the individuals' preventive behavior is affected by their beliefs in being at risk (perceived susceptibility), the seriousness of risk (perceived severity), existence of a way to reduce the incidence or severity of disease (perceived benefits), and higher costs versus the benefits of action (perceived barriers), and thus they participate in screening and prevention activities based on the evaluation of these factors $(13,14)$.

Given the pandemic and spread of SARS-COV-2, the observance of preventive health standards and behaviors in society is essential to better control the disease. Therefore, the present study was conducted to determine the preventive health behaviors from COVID-19 based on the health belief model among people in Golestan province in March 2019.

\section{Methods}

Procedure

The present cross-sectional study was conducted in a population of over 18 years of age in Golestan province in northern Iran from March 11 to 16, 2019. The participants were selected using the convenience sampling and they completed the electronic questionnaire. Generalities of the research were approved in Research 
Council of Golestan University of Medical Sciences and the National Ethics Committee in Biomedical Research with a code of IR.GOUMS.REC.1398.384. The questionnaire was forwarded via the virtual networks in Telegram and WhatsApp groups and channels, and the individuals were asked to optionally complete it and forward it to their friends and acquaintances. The approximate time to complete the questionnaire was about ten minutes, and it first started with an explanation of the research objectives.

\section{Measures}

The research tool included a questionnaire consisting of 5 sections, including demographic questions, health belief model construct questions, fatalism questions, clinical symptom recognition questions, and questions on the preventive behaviors from COVID-19.

1. Demographic questions: The section provided questions about age, gender, education, place of residence (city or village) and city of residence.

2. Questions about health belief model constructs, including 6 sections (questions about perceived susceptibility (3 questions), perceived severity (3 questions), perceived benefits (3 questions), perceived barriers (8 questions), sense of self-efficacy (1 question), and cues to action (two questions).

3. The fatalism section included two questions. All construct questions of the health belief model and fatalism were on a 5-point Likert scale (from strongly agree to strongly disagree), and their scores ranged from 1 to 5 .

4. Questions about recognizing the clinical symptoms of disease (7 questions) that were answered by yes, no and I don't know. The correct answer was scored 1, the wrong answer and I don't know were scored 0 .

5. There were 8 questions about the preventive behaviors from COVID-19. Answering the questions was on a 5 -point Likert scale from Always to Never; and scoring was from 1 to 5 .

The opinions of 8 health education and promotion specialists were used to determine the content validity; and the necessary changes and corrections were applied in the text of the questionnaire based on their opinions.

Analysis

First, the data were included in Mplus 7 software. Thereafter, the confirmatory factor analysis was used to investigate the relationship between each variable of the health belief model and fatalistic behaviors with individual behaviors about the prevention of COVID-19 for each variable, and then the desired structural models about relationships of each variable with the performance were inserted in the software. In each of these factor analyses, the factor score was calculated and stored for each variable. In the analyses, the goodness of fit indices, including the Root Mean Square Error of Approximation (RMSEA), Comparative fit index (CFI), Tucker Lewis index (TLI), and Standardized Root Mean Square Residual (SRMR) were used to judge the suitability of model. The Mann-Whitney test and Spearman's correlation analysis were relatively used to investigate the association between gender, residence place, and age with preventive behaviors from COVID-19. The factor scores in the simple linear regression analysis were used to investigate the effect of each construct on the performance of COVID-19 prevention behavior, and finally, effects of all constructs were examined simultaneously on COVID-19 preventive behavior using the multiple linear regression. The analyses were performed at a significance level of 0.05 using the SPSS 16. 


\section{Results}

Participants were in the age range of $15-77$ with an average age of $39.33 \pm 6.45$ years. 394 individuals ( $52.5 \%)$ were male, $74.9 \%$ lived in cities, and $57.1 \%$ had associate and bachelor's degrees. The mean scores of preventive behaviors from COVID-19 indicated significant differences with gender and residence place (Table 1).

The research results indicated that most participants (96.8\%) did not go to crowded places due to the prevention of the disease. $54 \%$ believed that people follow hygienic standards such as using masks, and hand washing to prevent the disease, while $25.2 \%$ believed that people never observe hygiene standards.

The results indicated that most respondents had relatively high perceived susceptibility, perceived severity, perceived benefits, and perceived self-efficacy, but lower perceived barriers and fatalistic beliefs (Table 2).

The vast majority of samples were aware of three main symptoms of COVID-19, including fever, dry cough, and shortness of breath (Table 3).

Table 4 presents the status of preventive behaviors from COVID-19. As shown $82 \%$ of participants "always" observed "no handshake and kissing", 73.7\% observed "hand washing when entering the house", 64.3\% observed "no need to leave the house", and $61.2 \%$ observed "the use of tissue paper or bending elbows when coughing and sneezing". $45.7 \%$ of samples always observed "washing hands with soap and water" and $39.7 \%$ always observed "a distance of one meter". The lowest levels of compliance were related to "touching face by hands" and "non-use of mobile phones outside the house", which were always observed by $33.5 \%$ and $22.8 \%$ of participants respectively (Table 4).

Table 5 presents mean scores (standard deviation) for constructs of the health belief model and fatalistic beliefs. The measured mean was obtained from dividing the mean score by number of questions in order to make the mean importance of each dimension comparable in participants. As presented, the "fatalistic beliefs" had the highest mean (4.13), followed by "perceived susceptibility" (3.03), "perceived barriers" (2.96), and "cues to action" (2.74). The lowest mean belonged to "perceived benefits" (1.83) and "preventive behaviors" (1.68) (Table 5).

Table 6 presents results of regression analysis (univariate, multivariate). The univariate analysis indicated that the self-efficacy, barriers, benefits, fatalism, cues to action, gender, and place of residence had significant effects on preventive behaviors from COVID-19. Multiple regression also indicated that self-efficacy, barriers, fatalism, gender, and place of residence were associated with preventive behaviors from COVID-19, and only the "cues to action" variable lost its significance. In this regard, the self-efficacy and perceived benefits had positive relationships; in other words, the mean score of performance increased with their increase, but the perceived barriers and fatalistic beliefs had opposite relationships and decreased the mean score of performance. Furthermore, the mean score of preventive behaviors against COVID-19 was higher in women than men and also higher in urban residents than villagers. As shown in the "standardized estimation" column of the table for comparing the effects of variables on performance, the greatest impact belonged to gender. The "perceived barriers" variable had a greater effect on preventive behaviors from COVID-19 than fatalism; 
and the individual's self-efficacy had a greater effect on the preventive behaviors from COVID-19 than the perceived benefits (Table 6).

\section{Discussion}

The present study aimed to determine the preventive behaviors from COVID-19 and roles of fatalistic beliefs and health belief model constructs in the disease in Golestan province of Iran. The results indicated that rate of adherence to preventive behaviors from COVID-19 was at a desirable level. Preventive behaviors such as observing the etiquette of coughing and sneezing, washing hands for at least 20 seconds, not kissing others, observing at least one meter distance from others, not leaving home except when necessary, not touching nose and face by hands, not taking a mobile phone with us out of house, and washing hands with soap and water as soon as arriving home were at proper levels. Results of a study in Hong Kong also indicated that more than 77 percent of participants reported good health performance for COVID-19 (15).

Gender was an important variable affecting the preventive behaviors, so that women showed better observance than men probably since they had greater motivation for health than men. In studies on breast cancer screening behaviors, the health motivation was confirmed as an independent variable (16-18). In a study by Lau et al. on the pandemic of H1N1 in women and men in Hong Kong, women had better performance than men in the prevention of the disease(19). Moreover, people living in cities showed better performance against the disease than villagers probably due to the difference in their literacy levels.

Perceived barriers and fatalistic beliefs were also inversely related to the preventive behaviors from COVID19. Therefore, the rate of adherence to preventive behaviors increased by reducing perceived barriers and fatalistic beliefs. However, the impact of perceived barriers was greater than fatalistic beliefs. The perceived barriers are important and effective constructs of the health belief model because the individuals should overcome barriers to behaviour despite their inner desire to engage in preventive behavior. Excessive barriers can be deterrents and prevent the creation of desired health behaviors. In the present study, the participants had fewer perceived barriers to preventive individual behaviors, such as hand washing, but they were strongly influenced by environmental barriers such as shortage of masks, alcohol pads, and disinfectants. Shortage of mask has been observed in most regions of world due to the pandemic of COVID-19(20,21) $(22,23)$ and the issue was also observed in the present study. In a recent study in China, shortage of mask in the market was a reason for not using it (24). Providing masks and other disinfectants and overcoming the environmental barriers can be effective in increasing the individuals' adherence to these preventive behaviors. The existence of high perceived self-efficacy is an important factor in overcoming the perceived barriers; and it was an effective variable in adopting preventive behaviors from COVID-19 in the present study. Self-efficacy is defined as the level of trust and confidence in overcoming barriers to a healthy behavior. According to the health belief model, individuals should have an appropriate level of self-efficacy to overcome barriers to behavior(25).

Fatalistic beliefs constitute a theory based on which people believe that events are controlled by external forces and humans have no power over them and can no longer influence them; and they are considered greatly as barriers to screening and preventive behaviors for cancers. They are more common in poor people, racial and ethnic minorities, and low-literate people (26-31). In the present study, the participants' fatalistic 
beliefs were low due to high levels of education and high urbanization. On the other hand, fatalistic behaviors have been studied and confirmed in diseases such as cancer, but COVID-19 is an infectious disease; and the process of its infection, like cancers, is multifactorial and sometimes unknown; and its cause is known to be a single virus. Perhaps this has also contributed to the lack of fatalistic beliefs in the participants.

Perceived benefits were other factors in predicting preventive behaviors from the disease. In other words, the individuals perform better by increasing the perceived benefits. Having perceptions such as effects of regular hand washing, use of personal protective equipment such as masks, and disposable gloves can lead to high perceived benefits, and they are thus strong motivations for taking preventive measures against this disease.

In the study, the perceived susceptibility and severity did not show any significant relationship in predicting the preventive behaviors from COVID-19 despite the fact that the significance level of perceived severity was 0.688 and close to the significance level. In general, the perceived threat construct was an important variable in taking preventive measures, so that the individuals should consider themselves susceptible to this disease and consider the severity of this disease to be dangerous. Unlike the present study, results of a study by Qian et al. in China indicated that the perceived severity was an important predictor of corona prevention behaviors in China(31). Results of a research by Li et al. also indicated that high perceived severity increased negative emotions, higher cellphone use, and caution in COVID-19(32). Furthermore, Kwok et al. investigated the early stages of COVID-19 in Hong Kong and found that the individuals had higher perceived susceptibility and severity of COVID -19 , so that 89 percent said that they were at risk for COVID-19 and 97 percent said that COVID-19 had severe symptoms(15). In the above studies, other constructs of the health belief model were not included in the study. Considering two options, I completely agree and agree, in the present study, $70.3 \%$ of participants considered themselves susceptible to coronavirus; and $72.6 \%$ considered the disease dangerous in the case of its perceived severity. In general, the perceived threat to COVID-19 is greater than H7N9 and SARS in China and Hong Kong $(33,34)$. Some studies indicate that the individuals, who knew themselves less susceptible to the disease, consider it a severe and dangerous disease $(35,36)$.

The research had three limitations: first, the data were collected from the digital space due to specific conditions caused by limitations of the disease; hence, it did not allow for random sampling to select individuals. Second, some people such as the elderly or low-income people might not have access to smartphones and not be evaluated. Third, the individuals' performance was based on self-reporting that should be considered in the data generalization.

\section{Conclusion}

The research results indicated that female gender, perceived barriers, perceived self-efficacy, fatalistic beliefs, perceived benefits, and living in the city respectively had the highest predictive power of preventive behaviors from COVID-19. Therefore, it is necessary to perform interventions to increase awareness in men to promote health behaviors. Inducing the benefits of preventative behaviors increases the perceived self-efficacy, and thus overcomes the barriers to preventive behaviors from COVID-19. It is suggested decreasing the fatalistic beliefs and paying more attention to people living in rural areas in order to promote preventive behaviors.

\section{Abbreviations}


COVID-19:Coronavirus disease;SARS-CoV-2: Severe acute respiratory syndrome coronavirus 2; H1N1: Hemagglutinin Type 1 and Neuraminidase Type 1 ;HBM:health belief model; RMSEA: Root Mean Square Error of Approximation; CFI: Comparative Fit Index; TLI: Tucker-Lewis Index; SRMSR: Standardized Root Mean Square Residual; NOVA:analysis of variance; SPSS: Statistical Package for the Social Sciences

\section{Declarations}

\section{Acknowledgements}

The authors are grateful to the Research and Technology Deputy of the University for the financial support and ethical approval of this study, as well as those who participated in the study.

\section{Authors' contributions}

AC and HS participated in Conceptualization, Project administration, Methodology, Supervision, Writing review \& editing.MAL contributed in Data curation and investigation. BP, AR, and MSH contributed in Formal analysis and data interpretation and early draft.

\section{Funding}

This work was supported by the Golestan University of Medical Sciences, Gorgan, Iran.

\section{Availability of data and materials}

The datasets used and/or analysed during the current study are available from the corresponding author on reasonable request

\section{Ethics approval and consent to participate}

Generalities of the research were approved in Research Council of Golestan University of Medical Sciences and the National Ethics Committee in Biomedical Research with a code of IR.GOUMS.REC.1398.384.

The below message was used as consent to participate:

The present questionnaire is about your beliefs regarding coronavirus prevention methods. The aim of this study was to determine the factors influencing the preventive behaviors of the new coronavirus. Please help us do this research with your honest answer. This questionnaire is anonymous, so there is no need to mention the name and surname. Completing the questionnaire will take about 7 minutes. It should be noted that your information will remain confidential. Generalities of the research were approved in Research Council of Golestan University of Medical Sciences and the National Ethics Committee in Biomedical Research with a code of IR.GOUMS.REC.1398.384.

\section{Consent for publication}

Not applicable. 
The authors declare that they have no competing interests.

\section{References}

1. Sahin AR, Erdogan A, Agaoglu PM, Dineri Y, Cakirci AY, Senel ME, et al. 2019 Novel Coronavirus (COVID19) Outbreak: A Review of the Current Literature. EJMO. 2020;4(1):1-7.

2. Thompson R. Pandemic potential of 2019-nCoV. The Lancet Infectious Diseases. 2020;20(3):280.

3. Chan JF-W, Yuan S, Kok K-H, To KK-W, Chu H, Yang J, et al. A familial cluster of pneumonia associated with the 2019 novel coronavirus indicating person-to-person transmission: a study of a family cluster. The Lancet. 2020;395(10223):514-23.

4. Sohrabi C, Alsafi Z, O’Neill N, Khan M, Kerwan A, Al-Jabir A, et al. World Health Organization declares global emergency: A review of the 2019 novel coronavirus (COVID-19). International Journal of Surgery. 2020.

5. Li Q, Guan X, Wu P, Wang X, Zhou L, Tong Y, et al. Early transmission dynamics in Wuhan, China, of novel coronavirus-infected pneumonia. New England Journal of Medicine. 2020.

6. Velavan TP, Meyer CG. The COVID-19 epidemic. Trop Med Int Health. 2020;25(3):278-80.

7. Guan W-j, Ni Z-y, Hu Y, Liang W-h, Ou C-q, He J-x, et al. Clinical characteristics of 2019 novel coronavirus infection in China. MedRxiv. 2020.

8. Zhao S, Lin Q, Ran J, Musa SS, Yang G, Wang W, et al. The basic reproduction number of novel coronavirus (2019-nCoV) estimation based on exponential growth in the early outbreak in China from 2019 to 2020: A reply to Dhungana. International Journal of Infectious Diseases. 2020.

9. Organization WH. Coronavirus disease 2019 (COVID-19): situation report, 72. 2020.

10. COVID C. Global Cases by Johns Hopkins CSSE. Gisanddata maps arcgis com Johns Hopkins University $(\mathrm{JHU})$.

11. Rosenstock IM. Historical origins of the health belief model. Health education monographs. 1974;2(4):328-35.

12. Rosenstock IM, Strecher VJ, Becker MH. Social learning theory and the health belief model. Health education quarterly. 1988;15(2):175-83.

13. Dodel M, Mesch G. Cyber-victimization preventive behavior: A health belief model approach. Computers in Human behavior. 2017;68:359-67.

14. Mo PK, Wong CH, Lam EH. Can the Health Belief Model and moral responsibility explain influenza vaccination uptake among nurses? Journal of advanced nursing. 2019;75(6):1188-206.

15. Kwok KO, Li KK, Chan HH, Yi YY, Tang A, Wei WI, et al. Community responses during the early phase of the COVID-19 epidemic in Hong Kong: risk perception, information exposure and preventive measures. medRxiv. 2020.

16. Nahcivan N, Seçginli S. Attitudes and behaviors toward breast cancer early detection: Using the health belief model as a guide. CU The Journal of School Nursing. 2003;7:33.

17. Ersin F, GÖZÜKARA F, Polat P, ERÇETIN G, Bozkurt ME. Determining the health beliefs and breast cancer fear levels ofwomen regarding mammography. Turkish journal of medical sciences. 2015;45(4):775-81. 
18. Nemcek MA. Health Beliefs and Preventive Behavior a Review of Research Literature. Aaohn Journal. 1990;38(3):127-38.

19. Lau JT, Griffiths S, Choi KC, Tsui HY. Avoidance behaviors and negative psychological responses in the general population in the initial stage of the H1N1 pandemic in Hong Kong. BMC Infectious Diseases. 2010;10(1):139.

20. Mahase E. Novel coronavirus: Australian GPs raise concerns about shortage of face masks. British Medical Journal Publishing Group; 2020.

21. Wu H, Huang J, Zhang CJ, He Z, Ming W-k. Facemask shortage and the coronavirus disease (COVID-19) outbreak: Reflection on public health measures. medRxiv. 2020.

22. Leung CC, Lam TH, Cheng KK. Mass masking in the COVID-19 epidemic: people need guidance. Lancet. 2020;395(10228):945.

23. Husnayain A, Fuad A, Su EC-Y. Applications of google search trends for risk communication in infectious disease management: A case study of COVID-19 outbreak in Taiwan. International Journal of Infectious Diseases. 2020.

24. Qian M, Wu Q, Wu P, Hou Z, Liang Y, Cowling BJ, et al. Psychological responses, behavioral changes and public perceptions during the early phase of the COVID-19 outbreak in China: a population based crosssectional survey. medRxiv. 2020.

25. Glanz K, Rimer BK, Viswanath K. Health behavior and health education: theory, research, and practice: John Wiley \& Sons; 2008.

26. Niederdeppe J, Levy AG. Fatalistic beliefs about cancer prevention and three prevention behaviors. Cancer Epidemiology and Prevention Biomarkers. 2007;16(5):998-1003.

27. Straughan PT, Seow A. Fatalism reconceptualized: a concept to predict health screening behavior. Journal of Gender, Culture and Health. 1998;3(2):85-100.

28. Pill R, Stott NC. Development of a measure of potential health behaviour: a salience of lifestyle index. Social Science \& Medicine. 1987;24(2):125-34.

29. Freeman HP. Cancer in the socioeconomically disadvantaged. CA: A Cancer Journal for Clinicians. 1989;39(5):266-88.

30. Perez-Stable EJ, Sabogal F, Otero-Sabogal R, Hiatt RA, McPhee SJ. Misconceptions about cancer among Latinos and Anglos. Jama. 1992;268(22):3219-23.

31. Powe BD. Cancer fatalism among elderly African American women: predictors of the intensity of the perceptions. Journal of Psychosocial Oncology. 2001;19(3-4):85-95.

32. Li J-B, Yang A, Dou K, Wang L-X, Zhang M-C, Lin X. Chinese public's knowledge, perceived severity, and perceived controllability of the COVID-19 and their associations with emotional and behavioural reactions, social participation, and precautionary behaviour: A national survey. 2020.

33. Lau J, Yang X, Tsui H, Kim J. Monitoring community responses to the SARS epidemic in Hong Kong: from day 10 to day 62. Journal of Epidemiology \& Community Health. 2003;57(11):864-70.

34. Wang L, Cowling BJ, Wu P, Yu J, Li F, Zeng L, et al. Human exposure to live poultry and psychological and behavioral responses to influenza A (H7N9), China. Emerging infectious diseases. 2014;20(8):1296. 
35. Enjezab B, Mojahed S, Bokaee M. Barriers and motivators related to cervical and breast cancer screening. SSU_Journals. 2004;12(3):78-84.

36. Champion VL. Instrument refinement for breast cancer screening behaviors. Nursing research. 1993.

\section{Tables}

Table 1: Frequency distribution of demographic variables of the participants

\begin{tabular}{lll}
\hline Variable & Group & Number (\%) \\
\hline Gender & Male & $394(52.5)$ \\
& Female & $356(47.5)$ \\
Residence place & Rural & $188(25.1)$ \\
& Urban & $562(74.9)$ \\
Education & Under high school diploma & $74(9.9)$ \\
& High school diploma & $109(14.5)$ \\
& Associate and bachelor's degree & $428(57.1)$ \\
& Master and higher & $139(18.5)$ \\
\hline
\end{tabular}

Table 2: Frequency distribution of answers to questions based on the fatalistic beliefs and health belief model constructs 


\begin{tabular}{|c|c|c|c|c|c|}
\hline Variable & $\begin{array}{l}\text { Strongly } \\
\text { agree } \\
\text { Percent- } \\
\text { No. }\end{array}$ & $\begin{array}{l}\text { Partially } \\
\text { agree } \\
\text { Percent- } \\
\text { No. }\end{array}$ & $\begin{array}{l}\text { No idea } \\
\text { Percent- } \\
\text { No. }\end{array}$ & $\begin{array}{l}\text { Partially } \\
\text { disagree } \\
\text { Percent- } \\
\text { No. }\end{array}$ & $\begin{array}{l}\text { Strongly } \\
\text { disagree } \\
\text { Percent- } \\
\text { No. }\end{array}$ \\
\hline \multicolumn{6}{|l|}{ Perceived susceptibility } \\
\hline $\begin{array}{l}\text { 1. I consider myself to be at risk of coronavirus. } \\
\text { 2. I am more likely to get the disease. }\end{array}$ & $\begin{array}{l}40.7- \\
305\end{array}$ & $\begin{array}{l}29.6- \\
222\end{array}$ & 9.7- 73 & 10.1- 76 & 9.9- 74 \\
\hline 3. I don't care about this disease and do my daily activities & & & $15.5-$ & $17.6-$ & 10.9- 82 \\
\hline like before. & $\begin{array}{l}24.8- \\
186\end{array}$ & $\begin{array}{l}31.2- \\
234\end{array}$ & 116 & 132 & $69.5-$ \\
\hline & $4.1-31$ & $6.1-51$ & 2.9- 22 & $\begin{array}{l}16.7- \\
125\end{array}$ & 521 \\
\hline \multicolumn{6}{|l|}{ Perceived severity } \\
\hline $\begin{array}{r}\text { 1. This disease has a high mortality rate. } \\
\text { 2. This disease is not very dangerous }\end{array}$ & $\begin{array}{l}33.9- \\
254\end{array}$ & $\begin{array}{l}32.4- \\
243\end{array}$ & 8.9- 67 & $\begin{array}{l}17.9- \\
134\end{array}$ & 6.9- 52 \\
\hline 3. The transmission power of this disease is high. & & & 4.9- 37 & & $46.7-$ \\
\hline & 3.5- 26 & $\begin{array}{l}19.1- \\
143\end{array}$ & $0.9-7$ & $\begin{array}{l}25.9- \\
194\end{array}$ & 350 \\
\hline & $\begin{array}{l}93.7- \\
7.1\end{array}$ & 4.9- 37 & & $0.3-2$ & 3- 0.4 \\
\hline \multicolumn{6}{|l|}{ Perceived barriers } \\
\hline $\begin{array}{r}\text { 1. It is difficult to follow the instructions to prevent this } \\
\text { disease. }\end{array}$ & $\begin{array}{l}13.9- \\
104\end{array}$ & $\begin{array}{l}31.7- \\
238\end{array}$ & 2.8- 21 & $\begin{array}{l}23.1- \\
173\end{array}$ & $\begin{array}{l}28.5- \\
214\end{array}$ \\
\hline 2. I don't have the patience to follow preventative & & & $4.1-31$ & & \\
\hline $\begin{array}{l}\text { instructions. } \\
\text { 3. It is difficult to wash hands regularly with soap and water. }\end{array}$ & $1.1-8$ & 8.5- 64 & 3.3- 25 & $\begin{array}{l}22.4- \\
168\end{array}$ & $\begin{array}{l}63.9- \\
479\end{array}$ \\
\hline 4. The mask is scarce in the market, and thus I do not wear a & $6-45$ & $16.9-$ & & & \\
\hline mask. & & 127 & $14.5-$ & $20.7-$ & $53.1-$ \\
\hline $\begin{array}{r}\text { 5. Disinfectant gels and solutions are scarce and expensive in } \\
\text { the market. }\end{array}$ & $\begin{array}{l}22.8- \\
171\end{array}$ & $23.1-$ & 109 & 155 & 398 \\
\hline 6. Alcohol pads are scarce in the market. & & 173 & 9.6- 72 & $17.7-$ & $21.9-$ \\
\hline 7. It is difficult not to touch hands, mouth, nose and eyes. & $59.3-$ & & & 133 & 164 \\
\hline \multirow[t]{4}{*}{ 8. Staying at home to prevent the disease is difficult. } & 445 & $\begin{array}{l}22.1- \\
166\end{array}$ & $\begin{array}{l}15.5- \\
116\end{array}$ & 4.5- 34 & 4.4- 33 \\
\hline & $\begin{array}{l}54.4- \\
408\end{array}$ & $\begin{array}{l}22.8- \\
171\end{array}$ & $4.2-32$ & $4.1-31$ & $3.2-24$ \\
\hline & $\begin{array}{l}20.1- \\
151\end{array}$ & $\begin{array}{l}37.6- \\
282\end{array}$ & 4.7- 35 & $\begin{array}{l}18.7- \\
140\end{array}$ & $\begin{array}{l}19.3- \\
145\end{array}$ \\
\hline & $\begin{array}{l}22.7- \\
170\end{array}$ & $\begin{array}{l}31.9- \\
239\end{array}$ & & $\begin{array}{l}15.5- \\
116\end{array}$ & $\begin{array}{l}25.3- \\
190\end{array}$ \\
\hline \multicolumn{6}{|l|}{ Perceived self-efficacy } \\
\hline & & & 5.5- 41 & 7.9- 59 & $3.1-23$ \\
\hline
\end{tabular}


I have ability to follow every preventive instructions against

the disease. 323

Perceived benefits

1. This disease can be easily prevented by washing hands $45.1-$ regularly with soap and water. 338

2. This disease can be easily prevented by personal 36.4-

protective equipment such as masks and disposable gloves. 273

Fatalistic beliefs

1. Having this disease is bad luck and the prevention has no 1.6- 12

effect. 6.5- 49

2. Catching or not catching the disease is out of my control.

Cues to action

TV and radio information about the disease has been helpful.

$27.2-$

28- 210

12.9- 97

5.3- 40

$16.5-$

72.1-

$15.2-$

114

11.2- $84 \quad 124$

$32.7-$

245

541

34.4-

258
20.4-

153

Table 3: Frequency distribution of answers to questions of clinical symptoms of COVID-19

\begin{tabular}{|c|c|c|c|}
\hline Questions & $\begin{array}{l}\text { Yes } \\
\text { No- } \\
\text { Percent }\end{array}$ & $\begin{array}{l}\text { No. } \\
\text { No- } \\
\text { Percent }\end{array}$ & $\begin{array}{l}\text { I don't } \\
\text { know } \\
\text { No- } \\
\text { Percent }\end{array}$ \\
\hline 1. Is headache a main symptom of this disease? & 273- 36.4 & 303- 4.4 & $174-23.2$ \\
\hline 2. Is runny nose a main symptom of this disease? & $211-28.1$ & 414- 55.2 & $125-16.7$ \\
\hline 3. Is fever a main symptom of this disease? & 701- 93.5 & 23- 3.1 & 26- 3.5 \\
\hline 4. Is dry cough a main symptom of this disease? & 717- 95.6 & 13- 1.7 & 20- 2.7 \\
\hline 5. Is shortness of breath a main symptom of this disease? & 731- 95.5 & 6- 0.8 & 13- 1.7 \\
\hline 6. Are body and muscle pain the main symptoms of this disease? & $451-60.1$ & $161-21.5$ & 138- 18.4 \\
\hline $\begin{array}{l}\text { 7. Are digestive problems (diarrhea and nausea) the main symptoms of this } \\
\text { disease? }\end{array}$ & 292- 38.9 & $277-36.9$ & $181-24.1$ \\
\hline
\end{tabular}

Table 4: Frequency distribution of conditions for observing preventive behaviors from COVID-19 


\begin{tabular}{|c|c|c|c|c|c|}
\hline Variable & $\begin{array}{l}\text { Always } \\
\text { No- } \\
\text { Percent }\end{array}$ & $\begin{array}{l}\text { Often } \\
\text { No- } \\
\text { Percent }\end{array}$ & $\begin{array}{l}\text { Sometimes } \\
\text { No- } \\
\text { Percent }\end{array}$ & $\begin{array}{l}\text { Rarely } \\
\text { No- } \\
\text { Percent }\end{array}$ & $\begin{array}{l}\text { Never } \\
\text { No- } \\
\text { Percent }\end{array}$ \\
\hline $\begin{array}{l}\text { 1. I place a tissue paper or bending elbow in front of my } \\
\text { mouth and nose when coughing or sneezing. }\end{array}$ & $\begin{array}{l}459- \\
61.2\end{array}$ & $\begin{array}{l}245- \\
32.7\end{array}$ & $32-4.3$ & $11-1.5$ & 3- 0.4 \\
\hline 2. I keep a distance of at least one meter from others. & $\begin{array}{l}298- \\
39.7\end{array}$ & $\begin{array}{l}352- \\
46.9\end{array}$ & 70- 9.3 & 25- 3.3 & 5- 0.7 \\
\hline 3. I don't shake hands with others and don't kiss them. & 615- 82 & $\begin{array}{l}102- \\
13.6\end{array}$ & 12- 1.6 & 4- 0.5 & $17-2.3$ \\
\hline 4. I don't leave the house unless absolutely necessary. & $\begin{array}{l}482- \\
64.3\end{array}$ & $\begin{array}{l}190- \\
25.3\end{array}$ & 40- 5.3 & 23- 3.1 & $15-2$ \\
\hline $\begin{array}{l}\text { 5. I wash my hands regularly with soap and water for at least } \\
20 \text { seconds every hour. }\end{array}$ & $\begin{array}{l}343- \\
45.7\end{array}$ & $270-36$ & 94- 12.5 & $31-4.1$ & 12- 1.6 \\
\hline 6. I do not touch my eyes, nose and mouth by hands. & $\begin{array}{l}251- \\
33.5\end{array}$ & $\begin{array}{l}381- \\
50.8\end{array}$ & 78- 10.4 & 29- 3.9 & 11- 1.5 \\
\hline 7. I do not take my cell phone out of my pocket. & $\begin{array}{l}171- \\
22.8\end{array}$ & $\begin{array}{l}264- \\
35.2\end{array}$ & $165-22$ & $\begin{array}{l}110- \\
14.7\end{array}$ & 40- 5.3 \\
\hline $\begin{array}{l}\text { 8. I wash my hands with soap and water without touching } \\
\text { anything after entering home. }\end{array}$ & $\begin{array}{l}553- \\
73.7\end{array}$ & 165- 22 & 24- 3.2 & 5- 0.7 & 3- 0.4 \\
\hline
\end{tabular}

Table 5: Frequency distribution of mean, standard deviation and standardized mean of fatalistic beliefs and health belief model constructs for preventive behaviors from COVID-19 in the participants

\begin{tabular}{llllllll}
\hline & $\begin{array}{l}\text { Number of } \\
\text { questions }\end{array}$ & $\begin{array}{l}\text { Range of scores for } \\
\text { questions }\end{array}$ & Mean & $\begin{array}{l}\text { Sd. } \\
\text { Standardized } \\
\text { mean }\end{array}$ & Minimum & Maximum \\
\hline Perceived & 3 & $1-5$ & 9.18 & 2.57 & 3.03 & 3 & 15 \\
susceptibility & & & & & & \\
Perceived severity & 3 & $1-5$ & 7.34 & 1.41 & 2.41 & 3 & 15 \\
Perceived barriers & 8 & $1-5$ & 23.7 & 6.11 & 2.96 & 8 & 40 \\
Perceived benefits & 2 & $1-5$ & 3.68 & 1.62 & 1.83 & 2 & 10 \\
Fatalistic beliefs & 2 & $1-5$ & 8.23 & 1.82 & 4.13 & 2 & 10 \\
Perceived self-efficacy & 1 & $1-5$ & 1.87 & 1.03 & 1.87 & 1 & 5 \\
Cues to action & 2 & $1-5$ & 5.48 & 2.05 & 2.74 & 2 & 9 \\
Recognition of clinical & 7 & $0-1$ & 4.4 & 1.49 & 0.62 & 0 & 7 \\
\multicolumn{1}{c}{ symptoms } & & & & & & & 8 \\
Preventive behaviors & 8 & $1-5$ & 13.51 & 4.17 & 1.68 & & 34 \\
\hline
\end{tabular}

Table 6: Effects of constructs of the health belief model, fatalistic beliefs, and demographic variables on preventive behaviors from COVID-19 


\begin{tabular}{|c|c|c|c|c|c|c|c|c|}
\hline & & Univariate a & halysis & & Multivariat & analysis & & \\
\hline & Estimation & $\begin{array}{l}\text { Confidence } \\
\text { interval }\end{array}$ & $\begin{array}{l}\text { Standardized } \\
\text { estimation }\end{array}$ & $\begin{array}{l}\mathrm{P} \text { - } \\
\text { value }\end{array}$ & Estimation & $\begin{array}{l}\text { Confidence } \\
\text { interval }\end{array}$ & $\begin{array}{l}\text { Standardized } \\
\text { estimation }\end{array}$ & $\begin{array}{l}\mathrm{P}- \\
\text { value }\end{array}$ \\
\hline $\begin{array}{l}\text { Perceived } \\
\text { self-efficacy }\end{array}$ & 0.12 & $0.1,0.14$ & 0.37 & $<0.001$ & 0.005 & $0.03,0.06$ & 0.22 & $<0.001$ \\
\hline $\begin{array}{l}\text { Perceived } \\
\text { susceptibility }\end{array}$ & -0.016 & $\begin{array}{l}-0.03 \\
0.001\end{array}$ & -0.06 & 0.067 & -0.006 & $-0.02,0.01$ & -0.02 & 0.45 \\
\hline $\begin{array}{l}\text { Perceived } \\
\text { severity }\end{array}$ & -0.02 & $-0.02,0.06$ & 0.04 & 0.3 & 0.03 & $\begin{array}{l}-0.002 \\
0.06\end{array}$ & 0.065 & 0.068 \\
\hline $\begin{array}{l}\text { Perceived } \\
\text { barriers }\end{array}$ & -0.21 & $-0.24,-0.19$ & -0.51 & $<0.001$ & -0.14 & $-0.18,-0.11$ & -0.36 & $<0.001$ \\
\hline $\begin{array}{l}\text { Perceived } \\
\text { benefits }\end{array}$ & 0.2 & $0.17,0.23$ & 0.4 & $<0.001$ & 0.07 & $0.03,0.11$ & 0.14 & 0.001 \\
\hline Fatalism & -0.4 & $-0.44,-0.34$ & -0.46 & $<0.001$ & -0.16 & $-0.23,-0.09$ & -0.19 & $<0.001$ \\
\hline $\begin{array}{l}\text { Cues to } \\
\text { action }\end{array}$ & 0.025 & $0.009,0.04$ & 0.11 & 0.002 & 0.01 & $-0.01,0.04$ & 0.04 & 0.4 \\
\hline $\begin{array}{l}\text { Recognition } \\
\text { of clinical } \\
\text { symptom of } \\
\text { the disease }\end{array}$ & -0.016 & $-0.1,0.06$ & -0.01 & 0.7 & 0.07 & $0.00,0.13$ & 0.06 & 0.051 \\
\hline $\begin{array}{l}\text { Gender }= \\
\text { Men- Women }\end{array}$ & -0.13 & $\begin{array}{l}-0.086 \\
-0.18\end{array}$ & -0.2 & $<0.001$ & -0.06 & $-0.08,-0.04$ & -0.42 & $<0.001$ \\
\hline $\begin{array}{l}\text { Place of } \\
\text { residence= } \\
\text { Urban- Rural }\end{array}$ & -0.09 & $\begin{array}{l}-0.15 \\
0.034\end{array}$ & -0.11 & 0.002 & -0.06 & $0.03,0.09$ & 0.24 & $<0.001$ \\
\hline Age & -0.01 & $-0.01,0.02$ & -0.02 & 0.55 & 0.001 & $\begin{array}{l}-0.005 \\
0.01\end{array}$ & -0.014 & 0.76 \\
\hline
\end{tabular}

$\mathrm{R}^{2}=0.484, \mathrm{R}_{\mathrm{adj}}{ }^{2}=0.476$ 